\title{
Myocardial infarction complicated by acute severe mitral regurgitation and cardiogenic shock. The importance of effective intra-aortic balloon pump therapy. A case report
}

Zawał serca powikłany dużą niedomykalnością zastawki mitralnej i wstrząsem kardiogennym. Znaczenie kontrapulsacji wewnątrzaortalnej w skutecznej terapii. Opis przypadku

\author{
Romuald Krynicki', ${ }^{1,2}$ Agnieszka Sobocińska ${ }^{1}$ \\ ${ }^{1}$ Institute of National Medicine, The State College of Computer Science and Business Administration, Lomza, Poland \\ 2Department of Cardiology, Hospital, Lomza, Poland
}

Postep Kardiol Inter 2012; 8, 4 (30): 351-356

DOI: $10.5114 /$ pwki.2012.31919

\begin{abstract}
Severe functional mitral regurgitation in acute myocardial infarction may be one of the main reasons for cardiogenic shock. According to data from the SHOCK registry, this happens in $6.9 \%$ of cases of acute myocardial infarction complicated by heart failure. The only way to significantly improve the prognosis is the use of intra-aortic balloon pump (IABP) and urgent coronary revascularization. We describe a patient with acute myocardial infarction without ST-segment elevation, complicated by severe mitral regurgitation, successfully treated with IABP and percutaneous coronary intervention of the infarct-related coronary artery.
\end{abstract}

Key words: myocardial infarction, cardiogenic shock, mitral regurgitation

\section{Streszczenie}

Duża czynnościowa niedomykalność zastawki mitralnej (mitral regurgitation - MR) w świeżym zawale serca (myocardial infarction - MI) może być jednym z zasadniczych powodów wstrząsu kardiogennego (cardiogenic shock - CS). Według danych rejestru SHOCK zdarza się to w około 7\% przypadków zawału powikłanego ostrą niewydolnością serca. Podobnie jak w każdej innej przyczynie CS wikłającego MI, jedynie zastosowanie balonu kontrapulsacyjnego (intra-aortic balloon pump - IABP) i wczesna rewaskularyzacja wieńcowa przynoszą największą korzyść choremu, gdyż zwiększają szanse przeżycia. Przedstawiono przypadek pacjenta z zawałem serca bez uniesienia odcinka ST powikłanym ciężką MR, skutecznie leczonego IABP i plastyką tętnicy wieńcowej odpowiedzialnej za zawał serca.

Słowa kluczowe: zawał serca, wstrząs kardiogenny, niedomykalność mitralna

\section{Introduction}

Severe functional mitral regurgitation (MR) complicating myocardial infarction (MI) may be one of the leading causes of cardiogenic shock (CS). According to data from the SHOCK registry it occurs in approximately $7 \%$ of cases of MI complicated by acute heart failure [1]. As in other causes of CS complicating acute myocardial infarction, intra-aortic balloon pump (IABP) and early percutaneous coronary intervention $(\mathrm{PCl})$ are the sole strategies bringing significant benefits to the patient and increasing the chance of survival [2].
We describe a case of a patient with non-ST-segment elevation MI complicated by severe MR successfully treated with $\mathrm{ABP}$ and $\mathrm{PCl}$ of the right coronary artery, which was the infarct-related artery.

\section{Case report}

A 75-year-old male patient with a history of anginal pain lasting approximately $1 \mathrm{~h}$ was admitted to the hospital around 12.20 a.m. directly from mushrooming. He did not have previous medical history. On admission the patient was in a severe general condition: pale skin,

Corresponding author/Adres do korespondencji:

Romuald Krynicki MD, PhD, Department of Cardiology, Hospital, 11 Piłsudski St, 18-400 Lomza, Poland, tel./fax: +48 864733265 ,

e-mail: a.s@kardiologia-lomza.pl

Praca wpłynęła: 28.07.2012, przyjęta do druku: 13.09.2012. 
peripheral cyanosis, systolic arterial blood pressure 60-70 $\mathrm{mm} \mathrm{Hg}$, diastolic pressure undetectable, muffled heart sounds, systolic murmur in the mitral area, bradycardia (46/min). ECG demonstrated sinus rhythm and signs of inferior, posterior and lateral left ventricular wall ischemia (mirroring Pardee wave?) (Fig. 1). The only abnormalities on laboratory examinations performed in the emergency room were elevated plasma glucose level (249 mg\%) and mildly elevated troponin I concentration $(0.54 \mathrm{ng} / \mathrm{ml}$, reference $<0.2$ ). The patient received a routine dose of $300 \mathrm{mg}$ of aspirin, $600 \mathrm{mg}$ of clopidogrel, $5000 \mathrm{IU}$ of unfractionated heparin i.v. and $1000 \mathrm{ml}$ of isotonic saline. However, this did not increase arterial blood pressure. Echocardio- graphic examination revealed diffuse left ventricular wall motion abnormalities affecting particularly the inferior and lateral wall and severe functional MR (+++/++++). Ejection fraction was $30 \%$. The patient was urgently transported to the catheterization laboratory. An IABP was introduced. Eptifibatide was administered. A rise of RR to 90-100/ $70 \mathrm{~mm} \mathrm{Hg}$ was observed already during coronary angiography. Coronary angiography demonstrated a proximally amputated circumflex artery (Cx), long borderline stenosis in the proximal and middle segment of the left anterior descending (LAD) artery, borderline stenosis in the middle segment of the recessive right coronary artery (RCA) and peri-mural lesions in other vessels (Fig. 2). The cir-
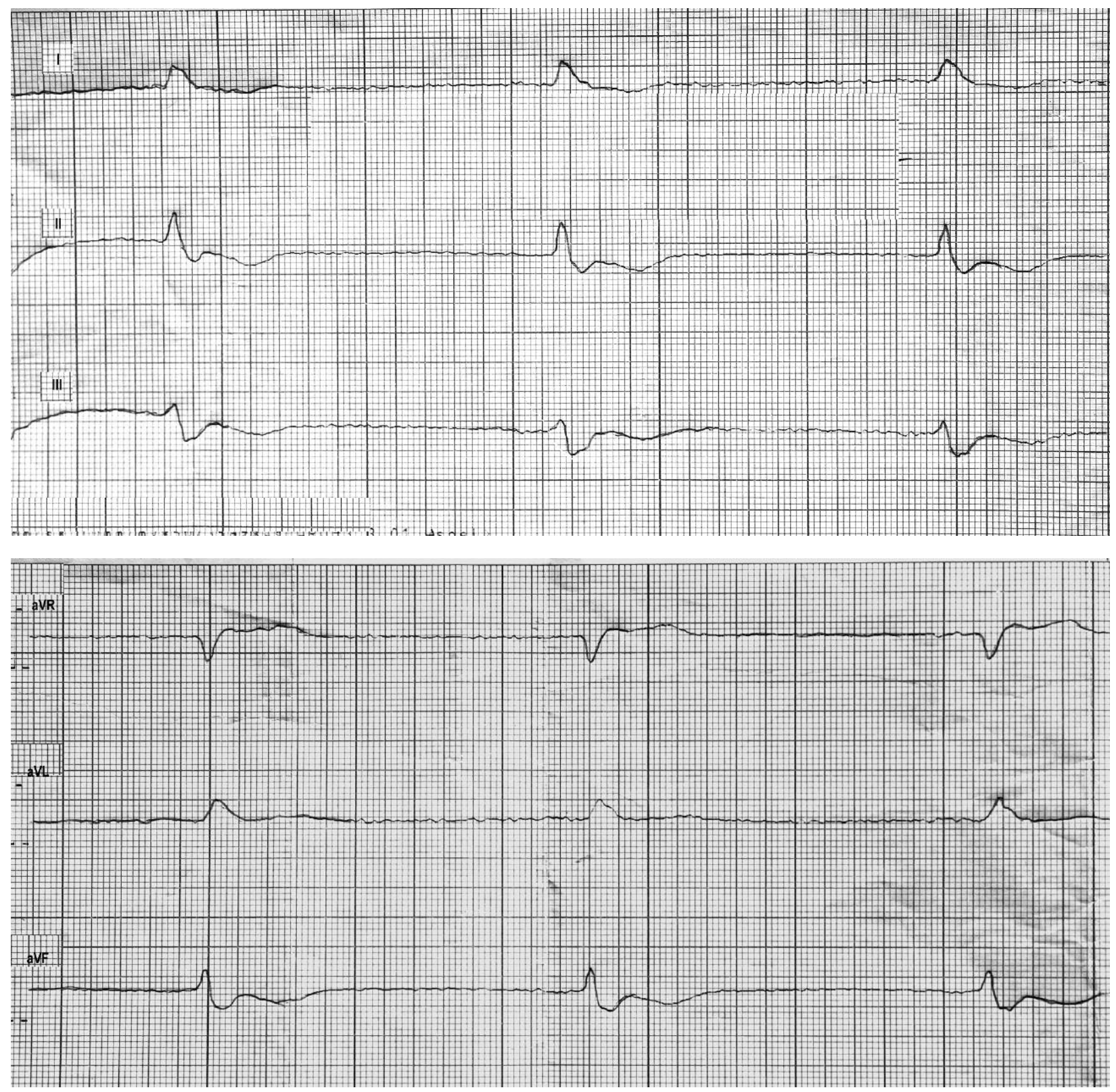

Fig. 1. Electrocardiograms on admission

Ryc. 1. Elektrokardiogram przy przyjęciu 

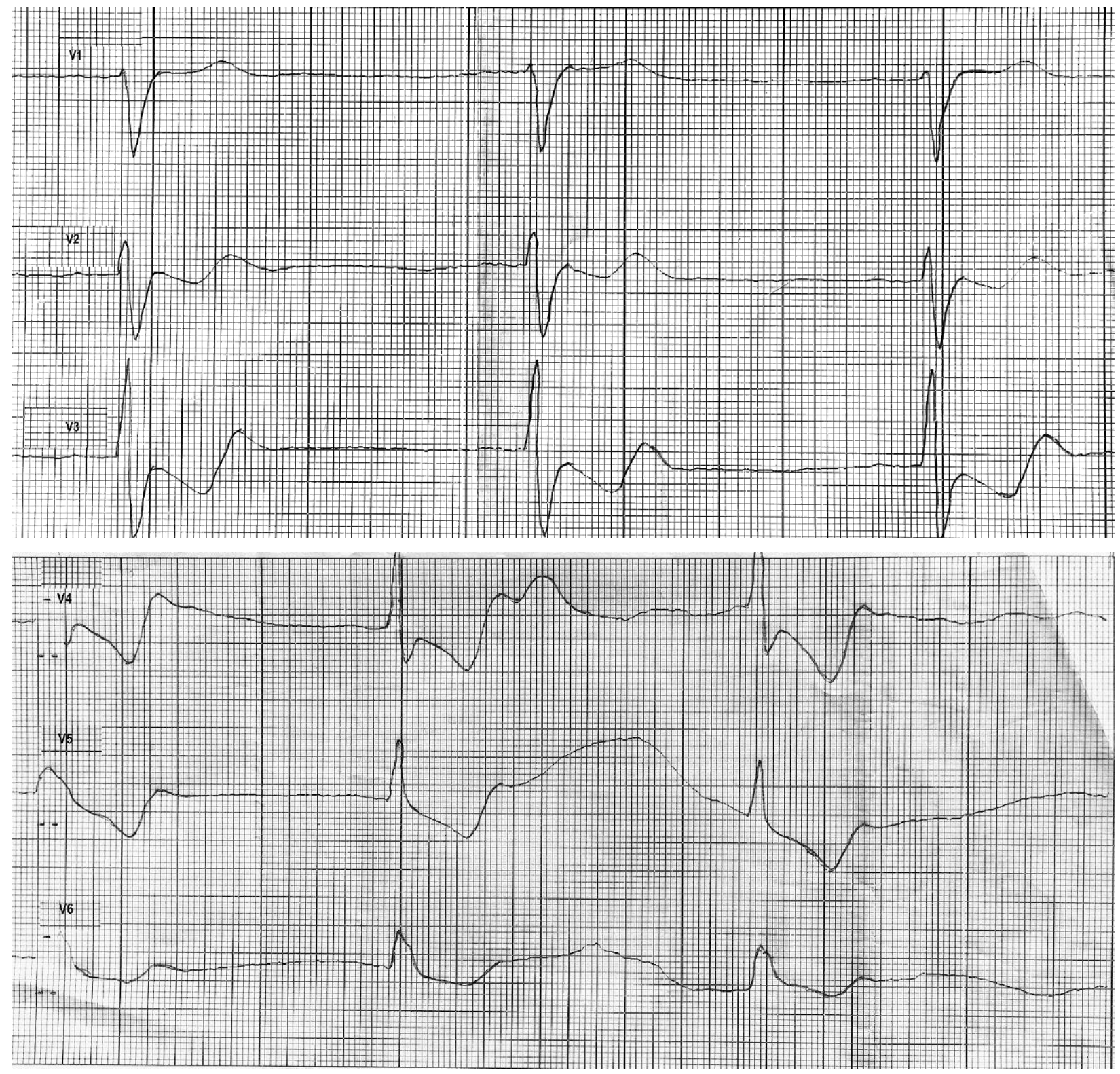

Fig. 1. Cont.

Ryc. 1. cd.

cumflex artery was pre-dilated with the $2.5 \mathrm{~mm} \times 20 \mathrm{~mm}$ Fryderyk balloon (12-16 atm), which was followed by $2.75 \mathrm{~mm} \times 28 \mathrm{~mm}$ Liberte BMS implantation (14 atm) leading to an optimal angiographic effect and restoration of TIMI III flow in the reopened vessel (Fig. 3). The circumflex artery turned out to be a very large, dominant vessel. The maximal troponin rise ( $>100 \mathrm{ng} / \mathrm{ml}$ ) was observed in the evening and on the second day of hospitalization. The glycemic profile on the second day of MI was normal (91 mg\%, 75 mg\%, 91 mg\%). Plasma lipid profile: total cholesterol - 138 mg\%, HDL - 68.8 mg\%, LDL - 61 mg\% (!), triglycerides $-42 \mathrm{mg} \%$. The patient's hemodynamic condition had practically stabilized already at the end of the
$\mathrm{PCl}$ (HR $80 \mathrm{bpm}, \mathrm{RR}$ 110/70 mm Hg). The IABP was removed on the third day of hospitalization. ECG stabilized (no Q waves were observed). ECG performed one day before discharge was similar to the one obtained several hours after $\mathrm{PCl}$ (Fig. 4). The following drugs were introduced on the fifth day of hospitalization: carvedilol $2 \times 3.125 \mathrm{mg}$, spironolactone $1 \times 25 \mathrm{mg}$ and furosemide $1 \times 1 \mathrm{tabl}$. in the morning. Control echocardiographic examination showed progressive improvement of the left ventricular contractility and reduction of the mitral regurgitation. Final examination on the day of discharge demonstrated $M R$ $(+/++)$ and left ventricular ejection fraction (EF) of $50 \%$ (!). The patient was discharged home on the $9^{\text {th }}$ day without 

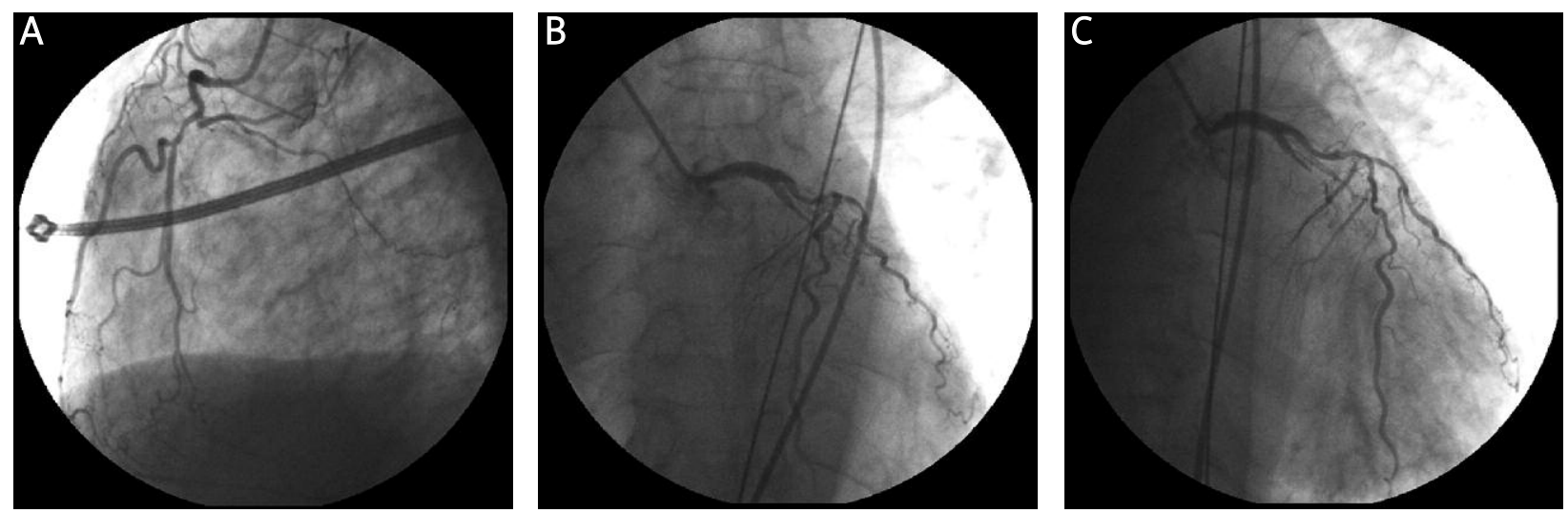

Fig. 2. Coronary angiography: A - right coronary artery, B, C - left coronary artery

Ryc. 2. Obraz tętnic wieńcowych w badaniu koronarograficznym: $A$ - prawa tętnica wieńcowa, $B, C$ - lewa tętnica wieńcowa
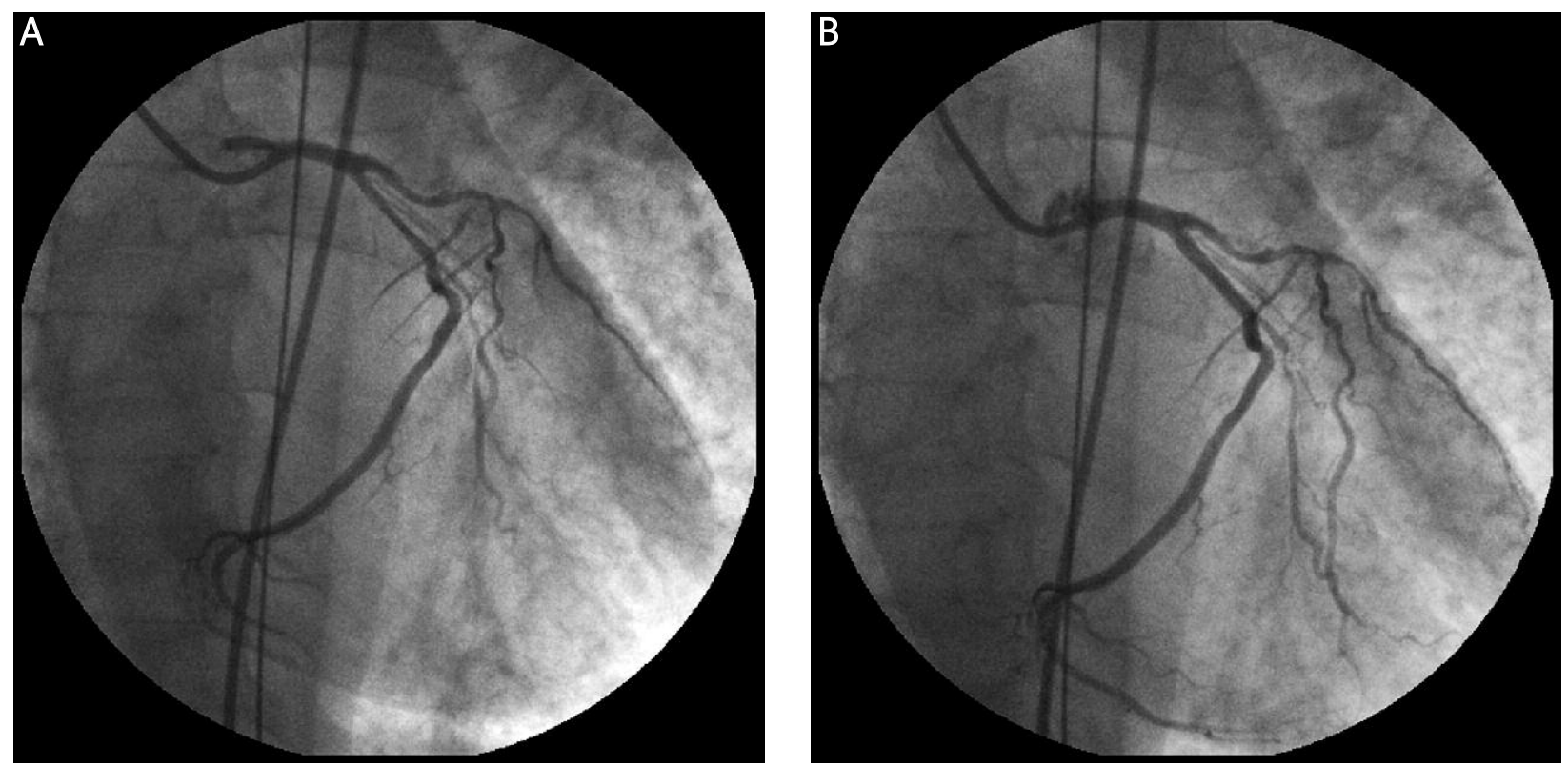

Fig. 3. Angiogram presenting final result after stent implantation

Ryc. 3. Angiogram przedstawiający końcowy wynik angioplastyki

any symptoms and instructed to undergo echocardiographic follow-up in 3 months time. The following medications were prescribed: clopidogrel $1 \times 1$ tabl., aspirin $1 \times$ $75 \mathrm{mg}$, atorvastatinum $40 \mathrm{mg} 1 \times 1$ tabl., ramipril $1 \times 5 \mathrm{mg}$, carvedilol $2 \times 6.26 \mathrm{mg}$, as well as furosemide $1 / 2 \mathrm{tabl}$. in the morning and spironolactone $1 \times 25 \mathrm{mg}$ with the recommendation to withdraw the latter two drugs after 1 month.

\section{Discussion}

Mitral regurgitation of various degrees is often observed in $\mathrm{MI}$ and according to many authors it may occur in up to $40-50 \%$ of all cases [3-5]. It is most often seen in infero-posterior wall infarctions, which is the area supplied by the right coronary artery or circumflex artery. It is caused directly by ischemia of the postero-lateral papillary muscle or less often by its rupture [6]. Occurrence of significant MR accompanied by left ventricular wall motion abnormalities is a threat to the patient leading to rapidly progressing CS. Severe MR coexisting with MI complicated by CS is present in 7\% of patients and interestingly more often in non-ST-segment myocardial infarction [1]. The diagnosis of MR is based on the detection of systolic murmur over the heart and on echocardiographic examination, which is used to determine the degree and cause (papillary muscle rupture vs. functional regurgitation) of MR. Further management depends on this diagnostic stage. The IABP should be undoubtedly used in each case of severe MR complicating myocardial infarction and progressing to shock irrespective of the cause of regurgita- 


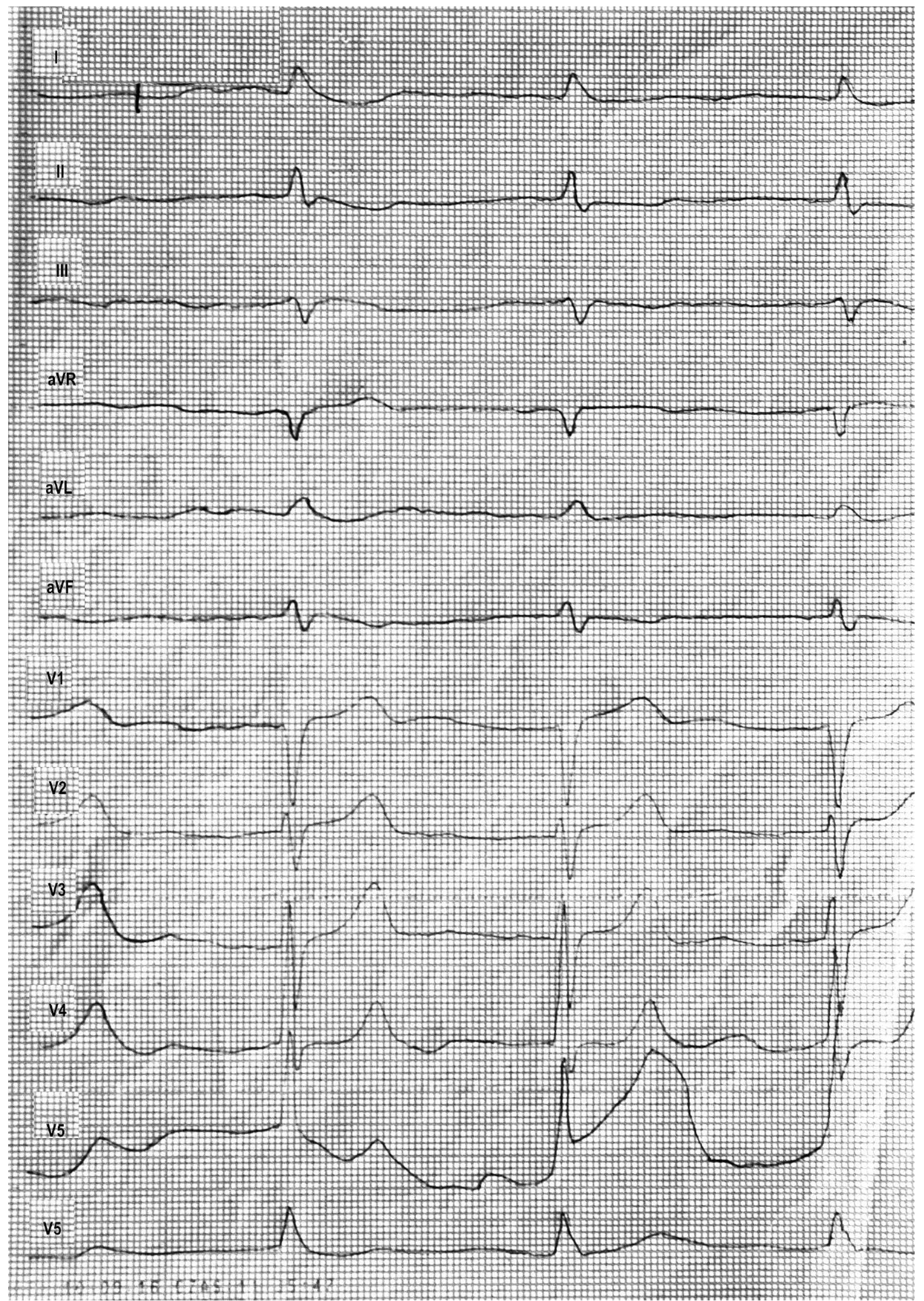

Fig. 4. Electrocardiograms of day before

Ryc. 4. Elektrokardiogram dzień przed wypisem 
tion and the method of treatment ( $\mathrm{PCl}$ vs. cardiac surgery) [1]. In our case the use of the IABP was necessary to increase arterial pressure and to improve coronary artery perfusion during $\mathrm{PCl}$, which led to reduction of MR. Because of the short history of anginal pain and low concentration of troponin at baseline, we suspected that the MR would be to a large extent reversible. This turned out to be true. The prognosis of patients with severe, acute and irreversible MR is relatively poor. They require urgent corrective surgery or mitral valve replacement, which remain a major challenge to the cardiac surgeon; the 30-day postoperative mortality may reach $20-40 \%$ irrespective of the method of treatment (valvuloplasty, valve replacement) [7-9]. Annuloplasty is used in later stages of functional ischemic MR and seems to improve the prognosis in patients with end-diastolic left ventricular diameter $<65 \mathrm{~mm}$ [10]. Based on many reports ischemic MR is an independent and important risk factor of progressive adverse left ventricular remodeling and heart failure and therefore any patient after myocardial infarction should undergo periodic echocardiographic examinations targeted also at the assessment of MR and its dynamic component $[4,5,11,12]$. Pharmacological treatment of $M R$ is based on the use of angiotensin-converting enzyme inhibitors and $\beta$-blockers [13]. However, our own experience shows that the dose of $\beta$-blocker, which is adequate and well tolerated by patients without MR, may increase heart failure despite achievement of the expected heart rate in patients with MR (?).

\section{References}

1. Hochman JS, Buller CE, Sleeper LA, et al. Cardiogenic shock complicating acute myocardial infarction: etiologies, management and outcome: a report from the SHOCK Trial Registry. SHould we emergently revascularize Occluded Coronaries for cardiogenic shock? JAm Coll Cardiol 2000; 36 (3 Suppl A): 1063-1070.

2. Lee KW, Norell MS. Cardiogenic shock complicating myocardial infarction and outcome following percutaneous coronary intervention. Acute Card Care 2008; 10: 131-143.

3. Bursi F, Enriquez-Sarano M, Nkomo VT, et al. Heart failure and death after myocardial infarction in the community: the emerging role of mitral regurgitation. Circulation 2005; 111: 295-301.

4. Aronson D, Goldsher N, Zukermann R, et al. Ischemic mitral regurgitation and risk of heart failure after myocardial infarction. Arch Intern Med 2006; 166: 2362-8.

5. Perez de Isla L, Zamorano J, Quezada M, et al. Prognostic significance of functional mitral regurgitation after a first non-STsegment elevation acute coronary syndrome. Eur Heart J 2006; 27: 2655-2660.

6. Thygesen K, Alpert JS, White HD; Joint ESC/ACCF/AHA/WHF task force for the redefinition of myocardial infarction. Universal definition of myocardial infarction. J Am Coll Cardiol 2007; 50: 2173-2195.

7. Tavakoli R, Weber A, Vogt $P$, et al. Surgical management of acute mitral valve regurgitation due to post-infarction papillary muscle rupture. J Heart Valve Dis 2002; 11: 20-5.

8. Lorusso R, Gelsomino S, De Cicco G, et al. Mitral valve surgery in emergency for severe acute regurgitation: analysis of postoperative results from a multicentre study. Eur I Cardiothorac Surg 2008; 33: 573-582.

9. Thompson CR, Buller CE, Sleeper LA, et al. Cardiogenic shock due to acute severe mitral regurgitation complicating acute myocardial infarction: a report from the SHOCK Trial Registry. SHould we use emergently revascularize Occluded Coronaries in cardiogenic shock? J Am Coll Cardiol 2000; 36 (3 Suppl A): 1104-1109.

10. Braun J, van de Veire NR, Klautz RJ, et al. Restrictive mitral annuloplasty cures ischemic mitral regurgitation and heart failure. Ann Thorac Surg 2008; 85: 430-436.

11. Carrabba N, Parodi G, Valenti R, et al. Clinical implications of early mitral regurgitation in patients with reperfused acute myocardial infarction. J Card Fail 2008; 14: 48-54.

12. Pérez de Isla L, Zamorano J, Quezada M, et al. Functional mitral regurgitation after a first non-ST-segment elevation acute coronary syndrome: contribution to congestive heart failure. Eur Heart J 2007; 28: 2866-2872.

13. Bursi F, Enriquez-Sarano M, Jacobsen SJ, Roger VL. Mitral regurgitation after myocardial infarction: a review. Am J Med 2006; 119: 103-112. 